\title{
PENERAPAN MODEL PROBLEM BASED LEARNING UNTUK MENINGKATKAN KEMAMPUAN MEMECAHKAN MASALAH PADA SISWA SMP
}

\author{
Sirtika Asrati ${ }^{1 *}$, Bhakti Karyadi ${ }^{1}$, Irwandi Ansori ${ }^{1}$ \\ ${ }^{1}$ Program Studi Pendidikan Biologi, Fakultas Keguruan dan Ilmu Pendidikan, Universitas Bengkulu \\ Email : sirtikaasrati4@gmail.com
}

\begin{abstract}
Abstrak
Penelitian ini bertujuan untuk mendeskripsikan penerapan model Problem Based Learning yang dilakukan guru dan kemampuan memecahkan masalah siswa kelas VII.c SMPN 9 Kota Bengkulu. Jenis penelitian ini adalah penelitian tindakan kelas dengan metode deskriptif. Penelitian ini terdiri dari dua siklus, setiap siklus terdiri dari 4 tahap yaitu tahap perencanaan, pelaksanaan, pengamatan dan refleksi. Subyek penelitian ini adalah guru dan seluruh siswa kelas VII.C SMPN 9 Kota Bengkulu. Variabel penelitian ini adalah model Problem Based Learning dan Kemampuan Memecahkan masalah siswa. Teknik pengumpulan data dalam penelitian ini yaitu observasi dan tes. Instrument penelitian yang digunakan adalah lembar observasi dan lembar tes. Hasil analisis data aktivitas guru siklus I diperoleh skor rata-rata yaitu 26 (Baik), dan pada siklus II skor aktivitas guru menjadi 30 (Baik). Hasil analisis data aktivitas siswa pada siklus I diperoleh skor rata-rata 26 (Baik), pada siklus II skor aktivitas siswa menjadi 30 (Baik). Data hasil kemampuan siswa memecahkan masalah pada siklus I dianalisis berdasarkan kategori ketuntasan belajar klasikal dan diperoleh persentase ketuntasan belajar klasikal yaitu 48\% yang termasuk dalam kategori belum tuntas dan pada siklus II kemampuan siswa memecahkan masalah mengalami peningkatan dengan ketuntasan belajar klasikal yaitu $87 \%$ dan termasuk dalam kategori tuntas. Dari hasil penelitian dapat disimpulkan bahwa model Problem Based Learning dapat meningkatkan kemampuan siswa memecahkan masalah.
\end{abstract}

Kata Kunci : Problem Based Learning, Kemampuan memecahkan masalah, Pengelolaan lingkungan.

\begin{abstract}
This research purposed to describe the implementation of Problem Based Learning model by teacher and the problem solve skill of students at class VII c SMPN 9 KOTA BENGKULU. The methodology used in this study was classroom action research with descriptive method. This research consists of two cycles, Each cycle consists of 4 stages that were planning, implementation, observation and reflection. The subjects of the study were the students in class VII.c SMPN 9 Kota Bengkulu. The variable from this research were Problem Based Learning model and the problem solve skill of student. Data were collected observation and test. The research instrument used was observation sheet and test sheet. The results of data analysis of teacher activity in first cycle obtained average score 26 (good predicate), while in second cycle the teacher activity score becomes 30 (good predicate). The result of data analysis of student activity on first cycle obtained average score 26 (good predicate), In second cycle the student activity score becomes 30 (good predicate). The data of the problem solve skill in first cycle was analyzed based on the classical learning completeness category was $48 \%$ which included in incompleteness category. While in the second cycle the problem solve skill of student had increased the good criteria of classical learning was $87 \%$ and included in the good criteria category. The research results the conclution of the result was problem based learning model can improve problem solve skill of students.
\end{abstract}

Keywords : Problem Based Learning, Problem solving skills, Environmental Management 


\section{PENDAHULUAN}

KTSP memuat berbagai mata pelajaran mulai dari tingkat Sekolah Dasar hingga Sekolah Menengah Atas.Salah satu mata pelajaran esensial di Sekolah Menengah Pertama adalah IImu Pengetahuan Alam (IPA). Menurut Trianto (2012) hakikat dan tujuan khusus pembelajaran IPA diharapkan salah satunya dapat memberikan keterampilan dan kemampuan untuk menangani peralatan, memecahkan masalah dan melakukan observasi. Dengan demikian, kemampuan memecahkan masalah sangat penting untuk dikembangkan pada pembelajaran IPA khususnya pada SMPN 9 Kota Bengkulu. Berdasarkan hasil observasi awal pada kegiatan magang III di SMPN 9 Kota Bengkulu khususnya dalam pembelajaran IPA, masih banyak siswa yang belum mampu mengembangkan kemampuan dalam memecahkan masalah, terlihat pada saat dilakukan pembelajaran dengan diskusi, siswa belum mampu berpikir dan menghubungkan setiap data yang mereka peroleh, siswa hanya terpaku dengan buku dan tidak mampu mengembangkan pola pikir mereka dalam menyelesaikan masalah.

SMPN 9 Kota Bengkulu menetapkan KKM (kriteria ketuntasan minimal) yaitu jika siswa mendapat nilai 76, Sehingga menurut guru persentase kemampuan anak dalam memecahkan masalah secara klasikal diperkirakan baru mencapai $40 \%$, hal ini dirasa masih belum cukup dan perlu ditingkatkan untuk mencapai persentase harapan guru sebesar $100 \%$. Upaya yang telah dilakukan oleh guru untuk mengembangkan kemampuan siswa dalam memecahkan masalah telah dilakukan dengan menerapkan metode diskusi. Namun, dikarenakan proses pembelajaran sebelumnya guru jarang menerapkan metode diskusi, lebih banyak menerapkan metode ceramah dan menuntut siswa mencatat materi di buku, siswa mengalami kesulitan ketika proses pembelajaran diubah dengan melakukan metode diskusi, siswa belum mampu mengembangkan keterampilan dalam memecahkan masalah yang didiskusikan. Kondisi proses pembelajaran tersebut perlu diperbaiki dengan cara mengembangkan pembelajaran yang inovatif melalui penerapan model yang memberi kesempatan kepada siswa untuk mengembangkan kemampuan memecahkan masalah yaitu model Problem Based Learning (PBL). Menurut Ibrahim (2012), PBL didefinisikan sebagai suatu model pembelajaran yang menggunakan masalah sebagai titik awal untuk mengakuisisi pengetahuan baru. Arends (2008) mengungkapkan bahwa esensi PBL berupa menyuguhkan berbagai situasi bermasalah yang autentik dan bermakna kepada siswa, yang dapat berfungsi sebagai batu loncatan untuk investigasi dan penyelidikan.

Model PBL merupakan model yang tepat untuk memperbaiki kondisi pembelajaran, dilihat dari uraian pengertian PBL dan juga pendapat Sujiono dan Arif (2014) bahwa proses PBL dapat memberikan kesempatan bagi siswa untuk melatih memecahkan masalah yang disajikan melalui beragam strategi dan taktik pemecahan masalah. Berdasarkan uraian di atas, peneliti dengan guru mata pelajaran IPA SMPN 9 Kota Bengkulu bekerjasama melakukan perbaikan pembelajaran IPA di kelas VIlc dengan menerapkan model PBL pada materi pengelolaan lingkungan melalui PTK untuk meningkatkan kemampuan siswa dalam memecahkan masalah.

\section{METODE}

Jenis penelitian yang digunakan adalah penelitian tindakan kelas (classroom action research). Metode dalam penelitian ini adalah deskriptif. Subyek dalam penelitian ini adalah guru IPA dan seluruh siswa kelas VIIC SMPN 9 Kota Bengkulu tahun ajaran 2016/2017. Teknik pengumpulan data yang digunakan dalam penelitian ini ada 2 cara, yaitu dengan observasi dan tes. Sedangkan instrumen penelitian yang digunakan yaitu lembar 
observasi dan lembar tes. Data pembelajaran model PBL dari pengamat I dan II di siklus I dan II dianalisis dengan rerata dan kategori rerata.

Data kemampuan memecahkan masalah siswa pada masing-masing siklus I dan II dianalisis secara deskriptif dengan rerata, kategori rerata dan presentasi kategori rerata. Rerata skor kemampuan memecahkan masalah menggunakan rumus menurut Sukardi (2012). Kategori kemampuan memecahkan masalah yang ditetapkan peneliti adalah tuntas dan tidak tuntas. Persentase ketuntasan kemampuan siswa memecahkan masalah dianalisis dengan mengunakan rumus menurut Sudijono (2012) yaitu:

$\mathrm{P}=(\Sigma \mathrm{X}) / \mathrm{N} \mathrm{X} 100 \%$

Keterangan rumus pada penelitian ini adalah:

$\Sigma \mathrm{X}=$ Jumlah siswa berkategori tuntas

$\mathrm{N}$ = Jumlah seluruh siswa

$\mathrm{P}=$ Angka persentase

\section{HASIL DAN PEMBAHASAN}

Berdasarkan penelitian yang telah dilakukan dengan menerapkan model problem based learning pada materi pengelolaan lingkungan, maka diperoleh hasil observasi aktivitas guru dan siswa pada pembelajaran model PBL, sebagai berikut :

Tabel 1. Aktivitas guru pada pembelajaran model PBL di siklus I dan siklus II

\begin{tabular}{|c|c|c|c|c|}
\hline \multirow[b]{2}{*}{$\begin{array}{c}\text { Penga } \\
\text { mat }\end{array}$} & \multicolumn{2}{|c|}{ Siklus I } & \multicolumn{2}{|c|}{ Siklus II } \\
\hline & $\begin{array}{l}\text { Total } \\
\text { Skor }\end{array}$ & $\begin{array}{c}\text { Katego } \\
\text { ri }\end{array}$ & $\begin{array}{l}\text { Total } \\
\text { Skor }\end{array}$ & $\begin{array}{c}\text { Kategor } \\
\mathbf{i}\end{array}$ \\
\hline 1 & 26 & Baik & 30 & Baik \\
\hline 2 & 26 & Baik & 30 & Baik \\
\hline Rerata & 26 & Baik & 30 & Baik \\
\hline
\end{tabular}

Dari Tabel 1. Hasil observasi yang telah dilakukan oleh dua orang pengamat terhadap aktivitas guru selama proses pembelajaran di siklus I dan siklus || sudah memperoleh kategori baik. Pada siklus I diperoleh skor 26 (Baik). Secara keseluruhan tahapan pada proses pembelajaran di siklus I dinilai baik oleh dua pengamat, namun masih terdapat beberapa aspek yang berkategori cukup.
Langkah/tahap pembelajaran yang masih dinilai cukup oleh kedua pengamat yakni : 1). Tahap orientasi siswa pada masalah di aspek menjelaskan tujuan pembelajaran PBL, menurut kedua pengamat pada kegiatan ini guru tidak menggunakan media dalam menjelaskan tujuan pembelajaran PBL kemudian pada tahap, 2). Tahap mengorganisasi siswa untuk belajar di aspek menjelaskan prosedur kegiatan pemecahan masalah, guru kurang rinci dalam menjelaskan prosedur kegiatan pemecahan masalah yang terdapat dalam LKS, 3). Tahap membimbing pengalaman individual/kelompok di aspek membimbing kelompok siswa pada saat mengkaitkan data hasil percobaan dengan konsep, 4).

Tahap menganalisis dan mengevaluasi proses pemecahan masalah di aspek membimbing siswa untuk menarik kesimpulan berdasarkan kegiatan yang telah dilakukan, menurut kedua pengamat, guru hanya membimbing sebagian besar kelompok siswa (4-5 kelompok). Pada siklus II semua tahapan sudah dinilai baik, sehingga rerata skor yang diperoleh lebih meningkat dibandingkan dengan siklus I yakni 30 dengan kategori baik. Langkah/tahap pembelajaran di siklus II semua sudah dinilai baik karena pada proses pembelajaran di siklus II, guru sudah menjalankan langkah/tahap pembelajaran yang benar dan tepat sesuai dengan tahap model PBL. Sedangkan hasil aktivitas siswa pada pembelajaran model PBL di siklus I dan siklus II di paparkan pada Tabel 2.

Tabel 2. Aktivitas siswa pada pembelajaran model PBL di siklus I dan siklus II

\begin{tabular}{ccccc}
$\begin{array}{c}\text { Pengam } \\
\text { at }\end{array}$ & \multicolumn{2}{c}{ Siklus I } & \multicolumn{2}{c}{ Siklus II } \\
& $\begin{array}{c}\text { Tota } \\
\text { I } \\
\text { Skor }\end{array}$ & $\begin{array}{c}\text { Katego } \\
\text { ri }\end{array}$ & $\begin{array}{c}\text { Tota } \\
\text { I } \\
\text { Skor }\end{array}$ & $\begin{array}{c}\text { Katego } \\
\text { ri }\end{array}$ \\
\hline 1 & 26 & Baik & 30 & Baik \\
2 & 26 & Baik & 30 & Baik \\
Rerata & 26 & Baik & 30 & Baik \\
\hline
\end{tabular}


Hasil observasi terhadap aktivitas siswa selama proses pembelajaran di siklus I dan siklus II sudah memperoleh kategori baik. Pada siklus I diperoleh skor 26 (Baik) dan pada siklus II diperoleh skor 30 (Baik). Dari hasil tersebut dapat dinyatakan terjadi peningkatan dari siklus I ke siklus II. Rerata skor observasi aktivitas siswa pada pembelajaran model Problem Based Learning di Siklus I yaitu 26 dengan kategori baik. Hampir keseluruhan observasi aktivitas siswa pada pembelajaran model Problem Based Learning di Siklus I dinilai baik, namun masih terdapat katergori cukup. Langkah/tahap pembelajaran yang masih dinilai cukup oleh kedua pengamat yakni : 1) Tahap orientasi siswa pada masalah di aspek perhatian siswa pada saat guru menjelaskan tujuan pembelajaran, pada kegiatan ini siswa hanya memperhatikan saat guru menjelaskan tujuan pembelajaran namun tidak mencatatnya, 2) Tahap mengorganisasi siswa untuk belajar di aspek aktivitas siswa dalam menanggapi guru pada saat menyampaikan prosedur kegiatan di LDS atau LKS yang akan digunakan dalam menyelesaikan masalah, hanya sebagian besar kelompok siswa yang memperhatikan saat guru menyampaikan prosedur kegiatan pada LDS atau LKS yang akan digunakan dalam menyelesaikan masalah, 3) Tahap membimbing pengalaman individual/ kelompok di aspek aktivitas anggota dari seluruh kelompok siswa pada saat berdiskusi terkait data hasil diskusi/ percobaan dengan konsep dan, 4) Tahap menganalisis dan mengevaluasi proses pemecahan masalah di aspek, aktivitas anggota seluruh kelompok siswa pada saat berdiskusi untuk menarik kesimpulan terkait penyelidikan yang telah dilakukan pada materi pengelolaan lingkungan,hanya sebagian besar kelompok siswa (4-5 kelompok) yang berdiskusi.

Pada siklus II rerata skor yang diperoleh lebih meningkat dibandingkan dengan siklus I yakni 30 dengan kategori baik. Pada Langkah/tahap pembelajaran di siklus II semua sudah dinilai baik dan mengalami peningkatan dari siklus I ke siklus II karena pada proses pembelajaran di siklus II, guru sudah menjalankan langkah/tahap pembelajaran yang benar dan tepat sesuai dengan tahap model PBL sehingga aktivitas siswa dalam proses pembelajaran juga meningkat.

Kemampuan siswa memecahkan masalah dinilai dari jawaban pertanyaan pada lembar tes yang dikerjakan secara individu. Berdasarkan penelitian yang telah dilakukan pada siklus I dan II diperoleh hasil rerata skor dan persentase kemampuan siswa memecahkan masalah yang dipaparkan pada Tabel 3 :

\begin{tabular}{cccc} 
Tabel 3. Nilai rerata dan & \multicolumn{1}{c}{$\begin{array}{c}\text { persentase } \\
\text { kemampuan } \\
\text { masalah siklus I dan siklus II } \\
\text { memecahkan }\end{array}$} \\
\hline & $\begin{array}{l}\text { Rata-rata } \\
\text { kemampuan } \\
\text { Siklus }\end{array}$ & $\begin{array}{l}\text { Jumlah } \\
\text { siswa } \\
\text { memecahkan } \\
\text { masalah }\end{array}$ & $\begin{array}{l}\text { Persentase } \\
\text { kemampuan } \\
\text { tuntas }\end{array}$ \\
$\begin{array}{llll}\text { memecahkan } \\
\text { masalah }\end{array}$ \\
\hline I & 67,67 & 16 & $48 \%$ \\
II & 86,57 & 29 & $87 \%$
\end{tabular}

\section{Kriteria kemampuan siswa} memecahkan masalah yang berkategori tuntas dinilai jika siswa menjawab semua pertanyaan dengan konsep dasar yang tepat serta dapat menjawab solusi dari masalah yang diberikan oleh guru. Pada siklus I ratarata nilai kemampuan siswa memecahkan masalah adalah 67,67 dengan jumlah siswa yang tuntas/mencapai nilai KKM ( $\left.{ }^{3} 76\right)$ adalah 16 orang sehingga diperoleh persentase kemampuan siswa memecahkan masalah yakni $48 \%$ sedangkan pada siklus II rata-rata nilai kemampuan siswa memecahkan masalah mengalami peningkatan yaitu 86,57 dengan jumlah siswa yang tuntas/mencapai nilai KKM (76) adalah 29 orang sehingga diperoleh persentase kemampuan siswa memecahkan masalah yakni $87 \%$. 
Berdasarkan hasil penelitian, kegiatan pembelajaran dengan model PBL yang dilakukan oleh guru selama dua siklus mengalami peningkatan pada siklus II. Hal ini ditunjukkan dari adanya peningkatan rerata skor observasi aktivitas guru dan siswa pada siklus I. Peningkatan ini terjadi karena adanya perbaikan aktivitas guru pada proses pembelajaran di siklus II. Menurut Asfadi (2015) Pengaruh yang terjadi dipengaruhi oleh beberapa keunggulan penggunaan model PBL yaitu siswa mampu berfikir kritis, mampu menyelesaikan masalah serta mampu mengalami pembelajaran secara langsung sehingga siswa akan lebih aktif dan ikut serta dalam kegiatan belajar daripada siswa yang masih menggunakan model pembelajaran konvensional.

Aktivitas guru pada proses pembelajaran dengan menggunakan langkahlangkah model PBL yang tepat dapat meningkatkan aktivitas siswa dalam proses pembelajaran karena proses pembelajaran dengan menerapkan model PBL memberikan kesempatan kepada siswa untuk lebih aktif dalam proses pembelajaran, pembelajaran tidak lagi terpusat pada guru, melainkan pada masing-masing siswa. Hal ini dikarenakan menurut Wulandari, dkk (2013) PBL memiliki beberapa kelebihan antara lain : 1) Pemecahan Masalah dalam PBL cukup bagus untuk memahami isi pelajaran, 2) PBL dapat meningkatkan aktivitas pembelajaran, 3) Membantu proses transfer siswa untuk memahami masalah-masalah dalam kehidupan sehari-hari, 4) Membantu siswa mengembangkan pengetahuannya, 5) Membantu siswa untuk memahami hakekat belajar sebagai cara berfikir bukan hanya sekedar mengerti pembelajaran oleh guru berdasarkan buku teks, 6) PBL menciptakan lingkungan belajar yang menyenangkan dan disukai siswa. Pada tahap PBL menuntut siswa untuk mencari informasi secara mandiri dari berbagai sumber yang berkaitan dengan masalah yang diberikan seperti yang dikemukakan oleh Arends (2008:392) Pembelajaran Berbasis Masalah (ProblemBased Learning/PBL) merupakan suatu model pembelajaran dimana siswa mengerjakan permasalahan yang otentik dengan maksud untuk menyusun pengetahuan mereka sendiri, mengembangkan keterampilan berpikir tingkat tinggi, dan mengembangkan kemandirian dan kepercayaan diri. Pengertian tersebut menggambarkan bahwaPBL, dapat menciptakan kondisi belajar yang aktif, dimana siswa dituntut untuk belajar memecahkan masalah melalui tahap-tahap metode ilmiah. Sehingga siswa memiliki pengetahuan yang luas dan ketrampilan ilmiah dalam menghadapi permasalahan. Aktivitas siswa pada tahap PBL yang dituntut untuk mencari informasi secara mandiri juga dapat meningkatkan kemampuan siswa dalam memecahkan masalah. hal ini dapat terlihat dari hasil kemampuan siswa memecahkan masalah pada proses pembelajaran dengan menerapkan model PBL di setiap siklus mengalami peningkatan.

Kemampuan siswa memecahkan masalah pada siklus I mencapai $48 \%$ dan di siklus II $87 \%$, hal ini menunjukkan kemampuan siswa memecahkan masalah mengalami peningkatan dibandingkan pada pembelajaran sebelumnya yaitu $40 \%$. Peningkatan kemampuan memecahkan masalah ini salah satunya dikarenakan siswa melakukan kegiatan diskusi pemecahan masalah menggunakan pembelajaran PBL yang tercermin pada LKS sehingga siswa dapat membangun pengetahuan sendiri dan pembelajaran yang dialami siswa akan lebih bermakna hal ini sesuai dengan beberapa teori belajar yang mendasari PBL yakni Teori belajar kognitif mengemukakan, bahwa belajar adalah suatu proses transformasi informasi dari stimulus menjadi sebuah perilaku atau pengetahuan yang tertata dalam bentuk struktur mental.

Pengetahuan tersebut diperoleh secara empiris berdasarkan pengalaman yang ditemukan dari lingkungannya. Teori belajar kognitif menjelaskan bahwa proses belajar akan berjalan baik bila materi pembelajaran 
yang baru dapat berasimilasi dan berdaptasi secara tepat dengan struktur kognitif yang telah dimiliki peserta didik. Asimilasi terjadi ketika pengetahuan baru masuk bergabung dengan pengetahuan yang sudah ada, sedangkan akomodasi terjadinya penyesuaian diri dengan informasi baru (Dahar, 2002:27). Dengan demikian proses belajar berlangsung berdasarkan pada skemata atau struktur mental dimana peserta didik akan mengorganisir informasi baru yang diperolehnya. Kaitan antara teori perkembangan kognitif dengan PBL adalah cara belajar siswa aktif yang dirancang untuk mengembangkan kemampuan intelektual melalui proses interaksi dengan lingkungan. Dengan demikian apabila fenomena lingkungan peserta didik dijadikan sumber kajian buku ajar diharapkan dapat membantu pemahaman siswa mengenai konsep-konsep lingkungan, sehingga pembelajaran menjadi lebih bermakna (Santrock, 2004: 46).

Menurut pembelajaran kontekstual, proses belajar didasarkan pada kebutuhan peserta didik, dan informasi yang disajikan berhubungan dengan pengetahuan yang telah dimiliki sebelumnya. Pembelajaran Kontekstual (Contextual Teaching Learning/CTL) mengasumsikan bahwa secara natural pikiran seseorang akan mencari makna yang sesuai dengan situasi lingkungan nyata dan memberi manfaat terhadap lingkungan. Memadukan materi pelajaran dengan pengalaman keseharian siswa akan menghasilkan dasar-dasar pengetahuan yang mendalam. Peserta didik akan mampu menggunakan pengetahuannya untuk menyelesaikan masalah-masalah baru yang belum pernah dihadapinya. Berdasarkan uraian di atas dapat disimpulkan. Pertama, pembelajaran kontekstual menekankan kepada proses keterlibatan siswa untuk menemukan materi. Kedua, pembelajaran kontekstual mendorong agar siswa dapat menemukan hubungan antara materi yang dipelajari dengan situasi kehidupan nyata. Ketiga, pembelajaran kontekstual mendorong siswa untuk dapat menerapkan pengetahuannya dalam kehidupan. Materi pelajaran dalam konteks pembelajaran kontekstual tidak untuk ditumpuk di otak dan kemudian dilupakan, tetapi sebagai bekal bagi mereka dalam kehidupan nyata (Mooji, 2007: 100-101). Hasil penelitian ini juga di perkuat dengan pendapat Yuniar (2015) bahwa PBL bertujuan untuk membantu siswa mengembangkan keterampilan berpikir tingkat tinggi dan basis pengetahuan disiplin substansial dengan menempatkan siswa dalam peran aktif baik dalam kelompok maupun individu, dihadapkan dengan situasi yang mencerminkan dunia nyata. Jadi, dapat disimpulkan bahwa penerapan model Problem Based Learning (PBL) pada proses pembelajaran dengan materi pengelolaan lingkungan dapat meningkatkan kemampuan siswa memecahkan masalah. Peningkatan kemampuan siswa memecahkan masalah ini dikarenakan guru memberikan kesempatan kepada siswa untuk lebih aktif dalam proses pembelajaran.

\section{PENUTUP \\ Kesimpulan}

Berdasarkan hasil dan pembahasan penelitian, simpulan dalam penelitian ini adalah sebagai berikut : 1) Perbaikan pembelajaran dengan menerapkan model PBL (Problem Based Learning) dalam proses pembelajaran materi pengelolaan lingkungan di kelas VII.c SMPN 9 Kota Bengkulu dapat meningkatkan aktivitas mengajar guru dan aktivitas belajar siswa hal ini dapat dilihat dari nilai rata-rata aktivitas guru dan siswa 26 menjadi 30 dengan kriteria baik.

2) Perbaikan pembelajaran dengan menerapkan model PBL (Problem Based Learning) dalam proses pembelajaran pada materi pengelolaan lingkungan di kelas VII.C SMPN 9 Kota Bengkulu dapat meningkatkan kemampuan memecahkan masalah siswa hal ini dapat dilihat dari nilai rata-rata kemampuan memecahkan masalah siswa 67,67 dengan persentase $48 \%$ (belum tuntas) menjadi 86,57 dengan persentase $87 \%$.

\section{Saran}


Saran yang perlu di pertimbangkan sebagai tindak lanjut terkait dengan penelitian yang telah dilakukan adalah sebagai berikut :

Model Problem Based Learning (PBL) merupakan model yang tepat digunakan untuk meningkatkan kemampuan siswa memecahkan masalah tetapi hendaknya memperhatikan tahap dari model pembelajaran ini, terutama pada tahap mengorganisasi siswa untuk belajar, guru dituntut untuk menjelaskan secara rinci kegiatan pemecahan masalah yang akan dilakukan sesuai dengan LKS/LDS yang digunakan, sehingga di tahap ini keterampilan menjelaskan perlu ditingkatkan.

Bagi peneliti lanjutan agar dapat melakukan penelitian lebih lanjut mengenai kemampuan memecahkan masalah dengan memperhatikan masalah yang akan diberikan kepada siswa dan tetap melakukan eksperimen di dalam kegiatan pembelajaran

\section{DAFTAR PUSTAKA}

Arends, R.I. 2008. Learning to Teach (Belajar Untuk Mengajar). Diterjemahkan oleh: Helly Prajjitno Soetjipto dan Sri Mulyantini Soetjipto. Yogyakarta: Penerbit Pustaka Pelajar.

Asfadi, Bayu. 2015. Pengaruh Model Pembelajaran Berbasis Masalah (Problem Based Learning) Terhadap Hasil Belajar Biologi Siswa Kelas X SMAN 3 Kota Jambi. Skripsi tidak diterbitkan. Jambi: Program Studi Pendidikan Biologi FKIP Universitas Jambi.

Badan Standar Nasional Pendidikan (BSNP). 2006. Panduan Penyusunan Kurikulum Tingkat Satuan Pendidikan Jenjang Pendidikan Dasar dan Menengah. Jakarta: BSNP.

Ibrahim, M. 2012. Pembelajaran Berdasarkan Masalah. Surabaya: Unesa University Press.
Ratna W Dahar. 2002. Teori Teori Belajar dan Pembelajaran. Jakarta: Erlanga

Sujiono \& Arif. 2014. Pengembangan Modul IPA Terpadu Berbasis Problem Based Learning Tema Gerak untuk Meningkatkan Kemampuan Berpikir Kritis Siswa. Unnes Science Education Journal, $\quad 3 \quad$ (3): 9 . http://journal.unnes.ac.id/sju/index.p hp/usej/article/view/2487

John W. Santrock. 2004. Education Psyshologi, 2ed (New Yok: McGraw-Hill

Sudijono, A. 2012. Pengantar Statistik Pendidikan. Jakarta: Rajawali Pers.

Sukardi, H.M. 2012. Evaluasi Pendidikan. Jakarta: Bumi Aksara.

Ton Mooij. 2007. Contextual learning theory: Concrete form and a software prototype to improve early education,n Computers \& Education 48 (diakses, Januari 2013),

Trianto. 2012. Model Pembelajaran Terpadu. Jakarta: PT Bumi Aksara.

Wulandari, Bekti dan Surjono, Hermawan Dwi. 2013. Pengaruh Problem Based Learning Terhadap Hasil Belajar Ditinjau Dari Motivasi Belajar PLC di SMK. Vol.3, 2 (http://journal.uny.ac.id/index.php/jp u/article/view/1600/1333) diakses 12 Juli 2017

Yuniar, TE dan Widodo, AT. 2015. Problem Based Learning Berpendekatan Seven Jumps Untuk Meningkatkan Hasil Belajar Siswa. Semarang: FMIPA Universitas Negeri Malang 